in Construction

Elsevier Editorial System(tm) for Automation

Manuscript Draft

Manuscript Number: AUTCON-D-16-00352R2

Title: The Building Information Modelling Trajectory in Facilities Management: A Review

Article Type: Review Article

Keywords: Building information modelling; data interoperability; facilities management; asset operations and maintenance

Corresponding Author: Miss Erika Anneli Pärn, BSc Architectural Technology, PGCert,

Corresponding Author's Institution: Birmingham City University

First Author: Erika Anneli Pärn, BSc Architectural Technology, PGCert,

Order of Authors: Erika Anneli Pärn, BSc Architectural Technology, PGCert, ; David J Edwards, BSc, PhD; Michael C Sing, BSc, PhD 


\section{HIGHLIGHTS}

- For new buildings, research into BIM-FM integration is rare.

- A review of developments and opportunities for BIM-FM integration is presented.

- Challenges posed include interoperability, performance enhancement and training.

- Future work seeks to produce commercial products and record contemporary practice. 


\title{
The Building Information Modelling Trajectory in Facilities Management: A Review
}

\author{
Pärn, E.A. ${ }^{1}$, Edwards, D.J. ${ }^{2}$ and Michael, C.P. Sing ${ }^{3}$ \\ ${ }^{1}$ Faculty of Technology Environment and Engineering, Birmingham City University \\ City Centre Campus, Millennium Point, Birmingham B4 7XG, United Kingdom \\ Email:Erika.Pärn@bcu.ac.uk (Corresponding Author) \\ ${ }^{2}$ Faculty of Technology Environment and Engineering, Birmingham City University \\ City Centre Campus, Millennium Point, Birmingham B4 7XG, United Kingdom \\ Email:David.Edwards@bcu.ac.uk \\ ${ }^{3}$ Department of Building and Real Estate \\ 7/F, Block Z, The Hong Kong Polytechnic University \\ Email: mcpsing@,outlook.com
}

\begin{abstract}
There is a paucity of literature that examines building information modelling (BIM) for asset management within the architecture, engineering, construction and owner-operated (AECO) sector. This paper therefore presents a thorough review of published literature on the latest research and standards development that impact upon BIM and its application in facilities management (FM) during the operations and maintenance (O\&M) phase of building usage. The purpose is to generate new ideas and provide polemic clarity geared to intellectually challenge readers from across a range of academic and industrial disciplines. The findings reveal that significant challenges facing the FM sector include the need for: greater consideration of longterm strategic aspirations; amelioration of data integration/ interoperability issues; augmented knowledge management; enhanced performance measurement; and enriched training and competence development for facilities managers to better deal with the amorphous range of services covered by FM. Future work is also proposed in several key areas and includes: case studies to observe and report upon current practice and development; and supplementary research related to concepts of knowledge capture in relation to FM and the growing use of BIM for asset management.
\end{abstract}

\section{KEYWORDS}

Building information modelling, data interoperability, facilities management, asset operations and maintenance 


\subsection{INTRODUCTION}

The proliferation of advanced computerisation throughout industry has revolutionised the way that buildings are designed, constructed, operated and maintained [1]. Today, computerisation is firmly embedded within a building's lifecycle from earliest concept through to occupation and operation, a transition made possible via disruptive technologies such as Building Information Modelling (BIM) which have displaced traditional approaches and created virtual communities of practice $(\mathrm{CoP})$ [2]. A virtual CoP represents an extensive 'multiple stakeholder' collaboration platform that is generated during design and construction through a single integrated BIM [1]. The dynamic, open access, digital environment afforded by BIM enables storage, sharing and integration of information for buildings' operations and management (O\&M) (ibid). BIM can embed key product and asset data within a three-dimensional computer model to effectively and efficiently manage building information [3] . Consequently, BIM deployment becomes extremely invaluable to organisations that seek to reap inherent value and efficiency gains from the technology $[4,5]$.

However, capturing a building's intricate and expanding portfolio of data requirements for facilities management (FM) is complex and requires facilities managers with tenacious strategic and tactical skills [6,7]. These skills encompass diverse roles and duties may include the strategic planning and management of: plant operations; computer systems analysis; building assets; interior operations; and day-to-day tactical operations of assets and staff [8]. The problems related to optimising O\&M are further exacerbated by the vast complexity and volume of data and information generated during a building's whole life cycle [9]. Automating this amorphous range of roles and duties, and engendering intelligent decision support, are feasible with the aid of BIM-FM integration $[10,11,12]$. However, within the UK, practitioners ${ }^{1}$ reside within a transition period of adopting BIM and the extant literature simultaneously discloses limitations in: related procedures [13]; established standards [12]; and computerised FM system integration [11]. Many practitioners have sought bespoke pathways to adopting new technologies in a climate of exponential technological advancement but few have sought guidance from more technologically advanced sectors as aerospace and automotive manufacturing [14]. Inconsistencies in technology adaptation are complicated by a paucity of standardisation within FM procedures and processes. At present, the literature contains limited evidence of applied studies of hybrid BIM-FM environment development and the tangible benefits to be accrued from such [12,9].

\footnotetext{
${ }^{1}$ Practitioners in the context of this paper includes all parties involved in construction project development including: client's estates department; construction manager; architect; mechanical electrical plumbing designer; structural engineer; sub-contractor; and consultant.
} 
To provide polemic clarity of the emergent hybrid BIM-FM environment, this research aims to: i) conduct a critical synthesis of extant literature and identify key challenges around BIM-FM integration; and ii) investigate state of-the-art tools used for BIM-FM knowledge capture. In realising these aims, the objectives are to argue the case for greater BIM-FM integration and stimulate wider debate and software development amongst academics and practitioners from a broader range of industrial sectors (including aerospace and automotive manufacturing). Knowledge transfer from these more technologically advanced industries will be beneficial to the AECO sector.

\subsection{FACILITIES MANAGEMENT: DEFINITIONS, INFLUENCES AND CHALLENGES}

FM represents an integrated approach to maintaining, improving and adapting an organisation's buildings to promote a fertile environment that supports the organisation's primary objectives $[15,16]$. Literature is replete with FM definitions, for example, Alexander [17] defines FM as: "the process by which an organization delivers and sustains support services in a quality environment to meet strategic needs." McGregor and Then [18] further proffer that FM is: "a hybrid management discipline, which combines the management expertise of people, property and process(es).(p.1)", whilst Nutt [19] defines FM as: “a supporting tool to obtain sustainable and operational strategy for an organisation over time through management of infrastructure resources and services.(p.462)". Chotipanich [20] elucidates the benefits derived from FM, highlighting improvements in managing facility resources, support services and working environment.

These delineations illustrate that the definition of FM has evolved over time and this can be attributed to several influential, interventional factors which impact upon the configuration of FM regime adopted. These factors can be conveniently allocated to three thematic groupings: i) business environment - including organisational structure [16,21]; business objectives [22]; and company culture and contextual issues [23]; ii) buildings and facilities characteristics - for example, facility type [23]; location; and size (ibid.); and iii) external interventions/ factors - such as business needs and processes [18]; asset maintenance priorities [24, 22]; legislation [21]; and interrelationships with other contractors [16]. In synthesising and evaluating the literature, Chotipanich [20] suggests categorising these factors as internal factors (i.e. characteristics of the organisation, facility features and business sectors) or external factors (i.e. social, economic, legislative and regulative, local culture and context and market context for FM) [25]. Appraising this eclectic mix of definitions and factors illustrates that internal factors have received wider attention vis-à-vis external factors, even though the latter are quintessentially important to organisational resilience and business stability [15]. 
Information is critical for supporting efficient and effective building maintenance and day-to-day operations $[15,24,26]$. However, the FM sector continues to grapple with information management, predominantly due to the peculiarity of information and its fragmentation [1,7]. These two causal factors are attributed as being the leading causes for knowledge loss within the architecture, engineering, construction, owner-operated (AECO) sector [27]. Computerisation alleviates asset information capture and retrieval, but knowledge capture and automated data analysis is limited within computer aided facilities management (CAFM) systems [15,11]. Commonly established CAFM tools are: computer aided design (CAD) (ibid.); integrated workplace management systems (IWMS) [28]; enterprise asset management (EAM) [29]; and computerized maintenance management systems (CMMS) [30]. Although these disparate tools have inherently different capabilities and functions, a vital prerequisite to implementing an appropriate CAFM system is that an organisation perceives data as its most invaluable asset [31]. A recent survey result is juxtaposed against this position and reveals that $43 \%$ of UK employees do not understand the value of business data [32].

The performance of FM must be measurable via knowledge management (KM) [33]. However, agreement over a common definition of KM remains a vexatious issue in FM [34,35,36]. For example, Bosch et al. [37] suggest that KM encapsulates a process of managing corporate knowledge to facilitate competitive advantage and organisational success, whilst Bhatt [38] emphasises KM characteristics and traits such as learning, collaboration, experimentation and implementation of powerful information systems. Commonly used FM performance measurement tools include: postoccupancy evaluation [38]; British Institute for Facilities Management (BIFM) measurement protocol [40]; key performance indicators (KPIs) [23]; and the balanced scorecard (BSC) [41] - refer to Table 1. Many of these tools are antiquated, often subjective and frequently client driven - consequently, they may fail to accurately portray issues facing the facilities management team (FMT) [33].

\section{$<$ Insert Table 1 FM performance measurement tools $>$}

\section{$2.1 \quad$ BIM-FM INTEGRATION}

The UK Government define BIM as: "a collaborative way of working, underpinned by digital technologies which unlock more efficient methods of designing, creating and maintaining assets" [63], whilst Succar [3] defines BIM as: "a set of interacting policies, processes and technologies producing a methodology to manage the essential building design and project data in digital format throughout the building's life-cycle." The capacity to harness valuable data and information throughout a building's life cycle is integral within these ubiquitous definitions (ibid). BIM has 
orchestrated a paradigm shift in the way that information is managed, exchanged and transformed to stimulate greater collaboration between stakeholders via a single integrated model during the design and construction phases [1]. This integrated approach to BIM ensures a smooth flow of information between all stakeholders and is specified and articulated through Levels of Development or Design [1,64] The Level of Design (LOD) is classified to range from LOD 100 (covering a conceptual 'low definition' design) to LOD 500 (for an as-built 'high definition' model). In practice, models that provide LOD500 are rare.

$\mathrm{BIM}$ and FM integration can be classified as 6D modelling (refer to Table 2) [65], where $\mathrm{nD}$ modelling is defined as the addition of supplementary information to three-dimensional model(s) for analysis and simulation purposes. BIM-FM integration is increasingly utilised for the building's O\&M and provides several benefits which include: augmented manual processes of information handover; improved accuracy of FM data (e.g. manufacturer specifications); and increased efficiency of work order execution to access data and locate interventions [66]. Watson [67] recommends that every constructed facility requires a bespoke BIM model, analogous to an owner's manual, with mandates for model updates that correspond to periodic repair or refurbishment works. In practice, 6D BIM data becomes the FMT's responsibility but this can create problems in other areas $[11,12,68]$. For example, Teicholz [26] reports a litany of issues including: inconsistent naming conventions; a myriad of bespoke FMT information requirements; inadequate data categorization in BIM and CAFM systems; poor information synchronization; and lack of methodology to capture existing facilities and assets. During O\&M, more than $80 \%$ of an FMT's time is consumed finding relevant information that is often disregarded by designers during pre-construction work [11]. Such information is important when handing-over an accurate as-built model to building owners for the purpose of asset management. The Institution of Civil Engineers [69] states that the provision of a reliable, BIM-sourced suite of information can eliminate these issues. A lack of tacit knowledge and technical expertise within the FMT represents a major obstacle to the ICE's (ibid) assertion.

\section{<Insert Table 2 Dimension of BIM>}

McArthur [71] contends that identifying information required to inform operational decisions is critical to configuring data retrieval techniques at the post-construction stages - yet this task, and linking such to the as-built model for O\&M usage, remains problematic [72]. Meadati et al. [73] observe that inconsistences between demand and availability of particular information in an as-built model incur unnecessary expenditures. Thus, linking data and configuring retrievable information 
within the as-built model for the project's post-construction operational phase must be considered during the design and development of BIM data.

BIM offers the FMT opportunities to manipulate and utilise information contained within 3D objects [74]. However, Lavy et al. [75] find that during the design phase, participants in a BIM project focus predominantly upon clash detections and ignore future-proofing maintenance accessibility. The authors (ibid) highlight potential in BIM for designers to explore the background geometry and parametric database and incorporate functions to assist the FMT anticipate and solve maintenance accessibility issues. Similarly, Meadati et al. [73] and Motawa and Almarshad [30] propose additional tools to improve BIM performance at the O\&M stage by more effectively engaging stakeholders. Longstreet [76] further adds that the value of implementing BIM increases exponentially as a project lifecycle unfolds. This is because BIM value in FM stems from improvements to: current manual processes of information handover; accuracy of FM data; accessibility of FM data; and efficiency increases in work order execution [12]. Consequently, FMT involvement during the BIM development process is essential because the building delivery team can be alerted of any issues related to O\&M. Interestingly, Bosch et al. [37] contradict this position and conclude that the current added value of BIM in the O\&M stage is marginal due to a lack of alignment between the supply of, and demand for, FM related information and the context-dependent role of information. Although this view ( ibid) is contrary to those stated within the broader academic discourse, it does resonate with Kassem et al. [12] who concede that BIM-FM integration represents a major challenge.

\subsection{INDUSTRY STANDARDISATION AND INTEROPERABILITY}

The FM industry standards acknowledge the importance of an organisation's strategic management of its property assets. ISO 55000 (ISO, 2014) for example, is regarded as the principal international document for establishing conformity in asset management, where asset management is defined as the: "coordinated activity of an organisation to realise value from assets." Other emergent standards (which cover building asset maintenance and management) include: PAS 55:2008 published by BSI; ISO 55001 and ISO 55002. Notably, the greatest influx of standardisation occurred between 20102014 such as ISO 16739: 2013 (covering industry foundation classes (IFCs)); PAS 1192:1,-5, (covering data format specification), ISO:29481;1, (covering BIM information manual). Importantly, these standards profoundly stress the standardisation of data exchange formats for improved semantic data interoperability. Figure 1 presents an abridged timeline overview of prominent UK and international standards governing FM, alongside the key developments in FM and BIM documentation in the UK. These standards provide coverage of: data management; naming 
conventions; common data environment; IFCs data management and interoperability; as well as construction information transfer. Construction Operations Building Information Exchange (COBie) standards (published since 2007 in the US and later adopted as British Standard in 2014) help to improve the handover of asset related data via the BIM model to the facility managers and/ or building owners [1,77]. This improvement is achieved by standardisation of data management in COBie for improved interoperability between BIM and CAFM systems [37].

$<$ Insert Figure 1 Development of BIM and FM standards $>$

\subsection{DATA INTEGRATION}

Data integration is embedded within the broader concept of interoperability between systems, services or programs [78] and is commonly defined as: "the combination of data from different sources with unified access to the data for its users" [79]. Inadequate data integration is a constant issue amongst building information modellers because of differences in syntax, schema or semantics. Multiple levels of data interoperability exist. However, out of the six levels of conceptual interoperability, 'semantic interoperability' is the one most applied to BIM data integration with other systems. Semantic heterogeneity of data results from different meanings or interpretations of data that may arise from various contexts (ibid). Hence, data integration and interoperability are inextricably linked when discussing BIM and other systems that need to integrate with it.

Data interoperability issues related to integration of BIM data with existing FM systems may be partly resolved through the use of ISO 16739 certification (ISO, 16739). The IFCs specification within ISO 16739 is an open and neutral data file format for data sharing and exchange within construction and FM, affording greater integration between BIM software vendors. IFCs is the only object orientated 3D "vendor-neutral BIM data format for the semantic information of building objects" [77]. IFCs models have been used as the file format for transferring BIM model data into CAFM tools due to the lack of interoperability between existing CAFM tools and the growing number of commercially available BIM packages [11]. Emerging literature on data integration between BIM and FM shows that software interoperability remains a significant and persistent obstacle $[11,80,81]$.

\subsection{BIM AS A FACILITATOR FOR FM EFFICIENCY}

Environmental impact and stricter environmental regulations have required the AECO sector to manage resources more efficiently [82]. This includes a building's O\&M costs which far exceed capital expenditures (CapEx) incurred during design and construction [21]. According to Mirjana and 
Milan [83], the cost of O\&M occupies more than $80 \%$ in the lifecycle of the building. The global economic crisis has further exacerbated the need for organisations to cut business overheads in response to tighter budgets [82]. Within this climate of financial austerity, BIM has been heralded as a facilitator for improvements in FM efficiency by enhancing the integration of FM related information $[82,11,84]$. These improvements are accrued during: the generation and management of a facility's digital specification and characteristics data; and cooperation between all parties involved in both building design and operation [20]. Consequently, BIM can overcome some of the complexity and fragmentation experienced within the FM sector [84].

The effective management of asset maintenance is heavily reliant upon continuous and reliable information on asset inventory, condition and performance [85]. Such non-geometrical information can be gathered and integrated with existing geometrical data retrievable in the BIM environment. This affords ease of access for information retrieval and enhanced visual recognition when locating facility assets [4]. Such measures provide substantial enhancements to traditional methods of managing assets during the O\&M phase; case studies of BIM applied to FM have demonstrated palpable long-term benefits for O\&M [86, 87]. An early case study observed a $98 \%$ reduction in time and resourcing for producing and managing an FM database through BIM [88]. Similarly, the Sydney Opera House case study demonstrates increased efficacy in data consistency, data mining and operating from a single source of information for the FMT [1]. Evidence also reveals how BIM has orchestrated efficient data retrieval and storage, and reduced time and resource spent on finding relevant equipment and building materials information [1,87]. Ding et al. [89] further reinforces these findings and reveals that BIM enabled FM witnessed a 98\% reduction in time used to update FM databases.

Implementing BIM in FM also allows asset owners to formulate intelligent decisions on facility related activities, and consequently optimize the outcome [75]. Because BIM facilitates collaboration and information integration during the O\&M phases, it is beneficial for processing large sets of complex information typically associated with maintaining building assets [4]. The aggregation of various FM information perspectives requires a high-level integration generated by different stakeholders using multiple sources such as maintenance records, work orders, causes and knock-on effects of failures [90]. It also describes how information flows through three different analysis nodes, namely: legal; technical; and administrative aspects. Each node produces outputs that are influential to others in order to correctly process and interpret data. However, when examining FM holistically and how extensive its information perspectives and disciplines are, it can be argued that three nodes cannot provide universal coverage of all sources of information flow. Given the inherent 
complexity of facilities and FM maintenance procedures, BIM process adaptation offers exciting opportunities for encapsulating such data for asset maintenance. Future research is needed to further substantiate the potential benefits afforded by BIM-FM integration using real life case-studies [11].

\subsection{OBSTACLES IN BIM-FM INTEGRATION}

As-built BIM models require data updates when maintenance work is conducted to ensure that the most recent asset history data is readily available for the FMT [24]. This movement towards BIM reuse for FM imposes new processes and tasks for the FMT, and represents a challenge for BIM-FM integration (ibid). For example, BIM and CAFM integration has been heavily criticized for limited data interoperability, namely the aptitude for transferring appropriate FM semantic data [13], whilst Bosch et al. [37] find the benefits of BIM for operations are marginal. Incongruence between the supply of, and demand for, information has also proved to be the key obstacle of BIM-FM integration. Although BIM enables greater data integration, such data is not necessarily presented in a pertinent semantic format for FM [91]. FMT involvement in the design and construction phase could improve interoperability of semantic data and hence the delivery of O\&M [75]. COBie has similarly been criticised for its inability to ensure comprehensive semantic data for FM and provide guidance for the design team on sourcing additional operational semantic data for FM [13]. Table 3 presents a critical synthesis and evaluation of the benefits derived from BIM-FM integration and the corresponding obstacles reported in the literature.

$<$ Insert Table 3 Overview of the commonly outlined benefits and corresponding obstacles in the BIM-FM integration>

Decision making for the O\&M of assets directly influences the annual expenditure of buildings [8]. However, accurate decision-making is unnecessarily convoluted given disintegration of multiple databases and data formats used [21]. Often decisions derive from various information sources (i.e. historical data, design drawings, inspection records and sensor data) which frequently reside in separate text-based spreadsheets [99]. Decisions based upon their large, textual based, data sets are unintuitive, time consuming and prone to human error (ibid.). Moreover, FM is inextricably linked to business operations within a building which vary building-to-building, hence the need for a tailored service $[100,18]$. The challenge is for BIM to provide strategic decision making for improved maintenance performance - often measured in terms of cost, time, health and safety, functionality and maintainability [101]. Successfully integrated CAFM and BIM systems provide an invaluable source of knowledge capture for existing facilities [102]. Figure 2 demonstrates how functions of existing maintenance processes have been integrated via BIM and CMMS, BIM and CAFM and in BIM 
Expert systems; it also illustrates that decision support and diagnosis is yet to be achieved using BIM systems or with BIM and CAFM systems.

Knowledge capture becomes beneficial for predictive and preventative maintenance where asset information and operation data is accumulated and turned into insights about FM [109,72]. A dearth of studies demonstrate initial concepts of knowledge capture in relation to FM and the growing use of BIM for asset management. Table 4 summarises these studies to provide a foundation for knowledge based predictive maintenance management with BIM. Hassanain et al. [110] were the first to propose an IFCs based data model for an integrated maintenance management system. Later, Hassanain et al. [109] proposed an object-oriented method for supporting the information exchange between different domains in an FM project which allows the computer applications used by all project participants to

Lin and $\mathrm{Su}$ [64] developed a BIM-based facility maintenance management system for the FMT in the O\&M phase - this allows the FMT to access and review 3D BIM models for updating maintenance records in a digital format. The study proved that the structured information handover is fundamental to implementing BIM for FM. Motamedi et al. [72] also applied information generated from BIM to detect failure patterns of building components. As IFCs (and model view definitions (MVD) integral within these) are published and maintained by the buildingSMART alliance, it is currently supported by circa 150 software applications worldwide and used throughout industry [117]. The interoperability of the IFCs format allows designers, contractors and the FMT to utilize different software through the entire building lifecycle and improve the building's maintainability. Motawa and Almarshad [30] developed knowledge-based Building Information Modeling (K-BIM) that has been highly advocated in the field of facility management. Unlike the traditional application of BIM, the K-BIM proposed to capture the failure-cause-effect pattern of the component failure and then link to the corresponding elements of the BIM.

Whilst an influx of innovative, state-of-the-art tools demonstrate knowledge capture, limited evidence exists to substantiate the presence of a systematic feedback loop from the FMT (reporting 
upon actual- vis-a-vis predicted-building performance) to other relevant stakeholders engaged earlier in the development (e.g. design team members, contractors and other parties within the supply chain). BIM is heralded as a new facilitator for collaboration, however the key beneficiaries of building performance knowledge should not be limited to the FMT in the post occupancy phase. In order to facilitate a CoP that could augment the performance of future building developments, such knowledge is most valuable when fed back to participating stakeholders during the design and construction phases. Optimising the effectiveness of knowledge generated will require existing and future generations of personnel to be fully trained and competent in computer software systems, applications and developments. Figure 3 presents a diagrammatic representation of the potential for a knowledge based feedback loop from BIM and FM data integration. This development could improve interoperability in several key areas. First, data pertaining to a building's operational performance during the O\&M phase allows clients to develop optimum strategic maintenance plans. Second, comparison between actual and predicted building performance will allow both designers and contractors to improve the performance of future building developments [13].

$<$ Insert Figure 3 Potential for the knowledge based feedback loop from BIM and FM integration>

\subsection{CONCLUSIONS}

The extant literature is replete with widespread endorsement for BIM, which is seen to expedite the enhancement in building data management throughout the building's life-cycle. The increased demand for data management due to computerisation within the AECO industry has engendered a shift in existing processes towards more model based collaboration that has impacted upon the way in which buildings are operated and maintained. BIM and computerised FM tools used to manage and operate building asset data are ubiquitous whilst FMT requirements are often unique and bespoke. While some academics expound the virtues of COBie, anecdotal evidence suggests that this one shoe fits all approach is not well received by practitioners - indeed, the general consensus appears to suggest that there is little value in collecting data for the sake of such. Nevertheless, the inherent complexity of FM maintenance procedures presents exciting opportunities for encapsulating rich semantic data within BIM at the earlier stages of the building life cycle (design and construction). This early integration of both geometric and semantic data would prove invaluable to the FMT during building occupancy, particularly with respect to monitoring building performance. In turn, a more accurate measurement of building performance in-use provides a virtual circle and invaluable knowledge based feedback opportunity for designers and contractors to improve the development of future projects commissioned. 
However, efficient utilisation and integration of complex FM semantic data in BIM poses three significant challenges. First, computerisation technology is developing at an exponential pace and hence, training personnel to keep abreast of the latest knowledge and developments can be problematic for industry. Higher education institutes (and other education providers) must collaborate more closely with practitioners to fully embrace the concept of a life-long learner in order to avoid tacit knowledge redundancy within the workforce. Second, there is a lack of alignment in the supply and demand of FM semantic data from project clients, which can also indicate an inadequate understanding in what semantic data is usable or required during the building's life cycle. Realising a solution to this issue will be multifaceted but is likely to include a combination of aspects relating to greater knowledge management, better education during building conception, supported by a robust form of procurement. Third, data within BIM for FM is not fully exploited for the decision support knowledge inherent within it. Therefore the opportunity to enhance a building's performance using rich semantic data is lost. This issue is further exacerbated by gaps in software interoperability when transitioning between as-built BIM and a CAFM system. Subsequently, the broad range of geometric and semantic data embedded in BIM model, points to the potential to augment data analysis and generate accurate knowledge capture and decision making. Opportunities are myriad but include the greater use of plug-ins to meet bespoke client requirements and machine learning algorithms to assist with the collation and interpretation of voluminous data accrued throughout the building's life cycle.

Future research is however needed to: i) further develop the concepts of, and applied methodological approaches for, knowledge capture in relation to FM and the growing use of BIM for asset management. Such work should aspire to produce tangible commercial products founded upon robust testing by scientific validation; ii) substantiate the potential benefits afforded by BIM-FM integration using real life case-studies as a means of broadening the industrial engagement, collaboration and future participation. To date, case studies of practice-based initiatives are scant or provide rudimentary insight into the myriad of opportunities available to clients and the building's FMT; and iii) conduct comparative analysis between BIM applications within the AECO sector and more technologically advanced industries such as aerospace and automotive. Such analysis may propagate the transference of readily available solutions to challenges reported upon in this paper. Automation within the BIM-FM integration process will revolutionise how buildings are conceived, developed, built and utilised - the challenges and opportunities identified here require innovative solutions to transform industry practice and should be augmented with far greater industry-academic collaboration and education. 
Table 1 FM performance measurement tools

\begin{tabular}{|c|c|c|}
\hline $\begin{array}{l}\text { Performance } \\
\text { Measurement } \\
\text { Tools }\end{array}$ & Definitions and Attributes & Authors \\
\hline $\begin{array}{l}\text { Post-occupancy } \\
\text { evaluation }\end{array}$ & $\begin{array}{l}\text { The evaluation of a building's performance in use by } \\
\text { auditing client satisfaction. Implemented at the } \\
\text { concluding stage of the design process, this can identify } \\
\text { potential system inefficiencies and improve design and } \\
\text { procurement for future projects. }\end{array}$ & {$[39,42,43,44,45]$} \\
\hline $\begin{array}{l}\text { Business } \\
\text { excellence } \\
\text { model (BEM) }\end{array}$ & $\begin{array}{l}\text { Represents a conceptual framework to measure business } \\
\text { performance, using processes based upon cause and } \\
\text { effect. More widely accepted and more effective than } \\
\text { other types of performance measurement tool. }\end{array}$ & {$[33,46,47,48]$} \\
\hline $\begin{array}{l}\text { Capability } \\
\text { maturity model } \\
(\mathrm{CMM})\end{array}$ & $\begin{array}{l}\text { A process maturity framework of five maturity levels } \\
\text { (the structural components that comprise the CMM } \\
\text { Software), based upon a software development } \\
\text { evaluation methodology which has been introduced to } \\
\text { other disciplines. }\end{array}$ & {$[33,49,50]$} \\
\hline $\begin{array}{l}\text { Balanced } \\
\text { scorecard (BSC) }\end{array}$ & $\begin{array}{l}\text { A semi-standard structured report used by managers to } \\
\text { monitor staff activities and any consequences arising } \\
\text { from these actions It may include additional perspectives } \\
\text { such as service, physical, financial, community, } \\
\text { environmental and utilisation. The most popular method } \\
\text { of measurement in the FM field. }\end{array}$ & {$[33,41,51,52,53,54]$} \\
\hline $\begin{array}{l}\text { BIFM } \\
\text { measurement } \\
\text { protocol }\end{array}$ & $\begin{array}{l}\text { Measures the effectiveness of facility management } \\
\text { operation in terms of cost and attempts to measure value } \\
\text { for money. Aims to resolve the problems resulting from } \\
\text { the amorphous range of services covered by FM and } \\
\text { represents a first step in the development of standardised } \\
\text { facilities management performance measurement. }\end{array}$ & {$[13,51,55]$} \\
\hline $\begin{array}{l}\text { Hierarchical } \\
\text { system of } \\
\text { performance } \\
\text { indicators }\end{array}$ & $\begin{array}{l}\text { Key performance indicators (KPIs) that have intrinsic } \\
\text { mutual relationships/ dependencies with other KPIs that } \\
\text { are linked through a hierarchal structure. }\end{array}$ & {$[56]$} \\
\hline $\begin{array}{l}\text { Benchmarking } \\
\text { and cost of } \\
\text { operation }\end{array}$ & $\begin{array}{l}\text { Benchmarking reflects the ethos of promoting } \\
\text { continuous improvement, determined from both within } \\
\text { and outside the organisation. It is the associated tool } \\
\text { used to achieve critical success factors such as } \\
\text { operational service efficiency }\end{array}$ & {$[57]$} \\
\hline $\begin{array}{l}\text { Key } \\
\text { performance } \\
\text { indicators } \\
\text { (KPIs) }\end{array}$ & $\begin{array}{l}\text { A performance measure of the success of an organisation } \\
\text { or activity in which it engages; performance indicators } \\
\text { are seen to deliver a service and are used to select } \\
\text { providers of FM; KPIs seek to benchmark industry } \\
\text { performance with a view to improving it; results show } \\
\text { that there is a relationship between types of maintenance } \\
\text { strategy implemented and end user satisfaction. Widely } \\
\text { used performance measurement tool in FM. }\end{array}$ & {$[23,58,59,60,61]$} \\
\hline $\begin{array}{l}\text { Input versus } \\
\text { output based } \\
\text { performance } \\
\text { measurement }\end{array}$ & Seeks to develop standardized performance metrics. & {$[51,62]$} \\
\hline $\begin{array}{l}\text { Service balanced } \\
\text { scorecard (SBS) }\end{array}$ & $\begin{array}{l}\text { A method for measuring facility performance that } \\
\text { encompasses financial and non-financial indicators. }\end{array}$ & [52] \\
\hline
\end{tabular}


Table 2 Dimensions of BIM

\begin{tabular}{|l|l|l|}
\hline \multicolumn{1}{|c|}{$\begin{array}{c}\text { Dimension of } \\
\text { Development }\end{array}$} & \multicolumn{1}{|c|}{ Descriptions } & \multicolumn{1}{|c|}{ Stakeholder Impact } \\
\hline 3D & $\begin{array}{l}\text { Consists of two and three dimensional model data to } \\
\text { represent the building design. 3D BIM can also be } \\
\text { defined as: "geometric presentation, parametric } \\
\text { descriptions and legal regulations associated with the } \\
\text { construction of a building” [70] }\end{array}$ & Design team, supplier \\
\hline $4 \mathrm{D}(3 \mathrm{D}+$ time $)$ & $\begin{array}{l}\text { Links scheduling/time related information to the 3D } \\
\text { model's objects in order to sequence the construction } \\
\text { process over time. [65] }\end{array}$ & Contractor, sub-contractor \\
\hline $5 \mathrm{D}(3 \mathrm{D}+\mathrm{cost})$ & $\begin{array}{l}\text { Adds cost related information to the 3D model's } \\
\text { elements. This enables early cost estimation and quantity } \\
\text { take offs directly from a single 3D file (ibid.). }\end{array}$ & Quantity surveyor \\
\hline $6 D(3 D+F M)$ & $\begin{array}{l}\text { Integrates FM and building lifecycle information. 6D is } \\
\text { related to asset information useful for facility } \\
\text { management processes, but after 5D no general } \\
\text { consensus on the dimensions has been reached in the } \\
\text { literature (ibid.). }\end{array}$ & $\begin{array}{l}\text { Facility manager, building } \\
\text { owner }\end{array}$ \\
\hline $\mathrm{nD}(3 \mathrm{D}+\ldots \mathrm{nD})$ & $\begin{array}{l}\text { Other possible dimensions associated with the BIM } \\
\text { model. }\end{array}$ & $\begin{array}{l}\text { Can relate to any specified } \\
\text { stakeholder. }\end{array}$ \\
\hline
\end{tabular}


Table 3 Critical overview of commonly outlined benefits associated with BIM and FM integration

\begin{tabular}{|c|c|c|c|}
\hline Benefit & Results & Authors & Limitations \\
\hline $\begin{array}{l}\text { Increased } \\
\text { utility and } \\
\text { speed for } \\
\text { data retrieval } \\
\text { from a } \\
\text { centralised } \\
\text { BIM model. }\end{array}$ & $\begin{array}{l}\text { Information is more } \\
\text { easily shared, can be } \\
\text { value-added, and } \\
\text { reused. }\end{array}$ & {$[26,37,75,92,93,94,98]$} & $\begin{array}{l}\text { Designers do not always know what } \\
\text { data is relevant to the FMT, slowing } \\
\text { down the process of COBie data drops. } \\
\text { Although BIM enables for more data } \\
\text { to be added this does not necessarily } \\
\text { mean it will be usable during the FM } \\
\text { stages. Data is not necessarily } \\
\text { presented in a usable format, survey } \\
\text { results illustrate that manual input can } \\
\text { take up to two years into CMMS after } \\
\text { the handover stages. }\end{array}$ \\
\hline $\begin{array}{l}\text { Enhanced } \\
\text { collaboration } \\
\text { through BIM } \\
\text { processes and } \\
\text { modelling. }\end{array}$ & $\begin{array}{l}\text { Built asset proposals } \\
\text { can be rigorously } \\
\text { analysed across } \\
\text { disciplines and } \\
\text { organisations. } \\
\text { Simulations can be } \\
\text { quickly executed and } \\
\text { performance } \\
\text { benchmarked, enabling } \\
\text { improved and } \\
\text { innovative solutions }\end{array}$ & {$[26,75,94,95,96,98]$} & $\begin{array}{l}\text { Collaboration between building } \\
\text { owners and the FMT at the design } \\
\text { stages is very limited. Little evidence } \\
\text { shows FM related constraints being } \\
\text { analysed in BIM. For example, } \\
\text { Lavy et al. [75] find that maintenance } \\
\text { accessibility tends to be ignored in the } \\
\text { design stages although collaboration is } \\
\text { facilitated through BIM. Collaboration } \\
\text { that is afforded with the design team } \\
\text { stakeholders for the design of the } \\
\text { building will not necessarily improve } \\
\text { upon how that building is to be } \\
\text { maintained in the latter stages. }\end{array}$ \\
\hline $\begin{array}{l}\text { Improved } \\
\text { embedded } \\
\text { building data } \\
\text { in a } \\
\text { centralised } \\
\text { model. }\end{array}$ & $\begin{array}{l}\text { Requirements, design, } \\
\text { construction, and } \\
\text { operational information } \\
\text { can be used in FM } \\
\text { resulting in better } \\
\text { management of assets. }\end{array}$ & {$[26,73,75,94,95,96]$} & $\begin{array}{l}\text { There are still many limitations with } \\
\text { BIM integration into existing CAFM } \\
\text { systems; this integration is necessary } \\
\text { as not all FM related information is } \\
\text { suitable for hosting in a BIM } \\
\text { environment. There is also a lack of } \\
\text { standardized tools and processes and } \\
\text { determining the specific data required } \\
\text { remains a key challenge for both the } \\
\text { design team members and the building } \\
\text { owner. }\end{array}$ \\
\hline $\begin{array}{l}\text { Visualisation } \\
\text { of assets. }\end{array}$ & $\begin{array}{l}\text { The value of 3D } \\
\text { visualization eliminates } \\
\text { misinterpretation. } \\
\text { Navigation of } \\
\text { information becomes } \\
\text { more fluent in a 3D } \\
\text { environment. }\end{array}$ & {$[37,94,95]$} & $\begin{array}{l}\text { Locating and navigating in a complex } \\
\text { BIM becomes difficult if GIS } \\
\text { information or barcoding is not linked } \\
\text { with the BIM model. }\end{array}$ \\
\hline $\begin{array}{l}\text { Longer } \\
\text { equipment } \\
\text { asset life. }\end{array}$ & $\begin{array}{l}\text { Through better } \\
\text { knowledge of existing } \\
\text { assets and CAFM } \\
\text { integration preparation } \\
\text { and planning enables } \\
\text { longer asset life. }\end{array}$ & {$[26,94,95,97]$} & $\begin{array}{l}\text { The learning process needs to be } \\
\text { facilitated during building operations } \\
\text { for better knowledge on asset } \\
\text { performance. Lindkvist [95] } \\
\text { highlighted the necessity of balance } \\
\text { between exploration and exploitation } \\
\text { of learning in order to shape BIM for } \\
\text { maintenance. }\end{array}$ \\
\hline $\begin{array}{l}\text { More } \\
\text { effective } \\
\text { space/ move } \\
\text { planning. }\end{array}$ & $\begin{array}{l}\text { In depth knowledge on } \\
\text { the assets that are fixed } \\
\text { or movable means } \\
\text { better space movement } \\
\text { can be planned and } \\
\text { executed. }\end{array}$ & {$[26,73,94]$} & $\begin{array}{l}\text { If RFID tags are not used this can limit } \\
\text { the accuracy of model data as it is so } \\
\text { heavily reliant on precise and up to } \\
\text { date information being added by the } \\
\text { management team. }\end{array}$ \\
\hline
\end{tabular}


Table 4 State of the art knowledge based decision tools in FM

\begin{tabular}{|c|c|c|c|}
\hline Use/Functionality & Methods & Authors & Limitations \\
\hline $\begin{array}{l}3 \mathrm{D} \text { visual approach for } \\
\text { maintenance management }\end{array}$ & $\begin{array}{l}\text { Utilises an external database and OpenGL technology. } \\
\text { Virtual facility provides administrators with component and } \\
\text { maintenance/ management information }\end{array}$ & [99] & $\begin{array}{l}\text { Requires a substantial amount of manual } \\
\text { data input in order to retrieve usable } \\
\text { information. No knowledge capture evident. }\end{array}$ \\
\hline $\begin{array}{l}\text { Roof maintenance } \\
\text { management }\end{array}$ & $\begin{array}{l}\text { Proposed IFCs-based data model for integrated maintenance } \\
\text { management for roofing systems. }\end{array}$ & {$[110]$} & $\begin{array}{l}\text { Lacking integration of network based data, } \\
\text { e.g. weather conditions that may impact } \\
\text { upon maintenance. }\end{array}$ \\
\hline Visualizer & $\begin{array}{l}\text { An interactive and graphical, decision-support tool for } \\
\text { service life prediction for asset managers. }\end{array}$ & {$[111]$} & $\begin{array}{l}\text { Limited in showing how learning can occur } \\
\text { for an organisation. }\end{array}$ \\
\hline $\begin{array}{l}\text { Object-oriented method of } \\
\text { asset maintenance } \\
\text { management. }\end{array}$ & Supports information exchange among different domains. & {$[109]$} & $\begin{array}{l}\text { Does not reveal knowledge capture } \\
\text { capacity, merely sets the stage for it. }\end{array}$ \\
\hline $\begin{array}{l}\text { Decision support for } \\
\text { maintenance evaluation and } \\
\text { suggestion }\end{array}$ & $\begin{array}{l}\text { A problem-oriented method of diagnosis of human diseases } \\
\text { known as Building Medical Record (BMR) adopted for } \\
\text { maintenance engineers, and contractors to access } \\
\text { information for evaluations and maintenance suggestions. }\end{array}$ & {$[112]$} & No use of BIM data evident \\
\hline $\begin{array}{l}\text { Framework for facilities } \\
\text { knowledge mapping }\end{array}$ & $\begin{array}{l}\text { The study reveals the main benefits of knowledge mapping } \\
\text { for FM: improvements in decision making process, problem } \\
\text { identification and solving by providing quick access to } \\
\text { critical information, knowledge gaps and island of expertise. }\end{array}$ & {$[113]$} & $\begin{array}{l}\text { This framework does not mention how BIM } \\
\text { data could be utilised in knowledge } \\
\text { mapping. }\end{array}$ \\
\hline $\begin{array}{l}\text { Diagnosis of the facility when } \\
\text { making decisions }\end{array}$ & $\begin{array}{l}\text { Extension of BMR called Building Diagnosis Navigation } \\
\text { System to support on-site managers during the diagnosis of } \\
\text { the facility when making decisions about treatment options. }\end{array}$ & {$[114]$} & No use of BIM data evident \\
\hline $\begin{array}{l}\text { Navigational algorithm in } \\
\text { BIM for asset management }\end{array}$ & $\begin{array}{l}\text { For effective utility maintenance management of facilities } \\
\text { equipped with passive Radio Frequency Identification } \\
\text { (RFID). }\end{array}$ & {$[115]$} & $\begin{array}{l}\text { Requires RFID tags, and ignores facilities } \\
\text { that may simply be using BIM model data } \\
\text { linked into existing CAFM or CMMS } \\
\text { system. }\end{array}$ \\
\hline $\begin{array}{l}\text { FM visual analytics system } \\
\text { (FMVAS) for failure detection }\end{array}$ & Knowledge capture for root cause failure detection in FM. & {$[94,72]$} & $\begin{array}{l}\text { Limited in showing knowledge capture as a } \\
\text { method. }\end{array}$ \\
\hline $\begin{array}{l}\text { Knowledge based FM using } \\
\text { BIM (K-BIM) }\end{array}$ & $\begin{array}{l}\text { As constructed information of the facility has the capability } \\
\text { for effective and efficient FM and thereby, enhances the } \\
\text { competitive advantage of a FM organisation. }\end{array}$ & {$[116]$} & $\begin{array}{l}\text { Demonstrates limited learning capacity with } \\
\text { K-BIM system (i.e. diagnosis of potential } \\
\text { issues). }\end{array}$ \\
\hline $\begin{array}{l}\text { Case-based reasoning and } \\
\text { BIM systems for asset } \\
\text { management }\end{array}$ & $\begin{array}{l}\text { An integrated system to capture, retrieve and manage } \\
\text { information/ knowledge for the key asset management } \\
\text { operation of building maintenance (BM). This aims to } \\
\text { establish the concept of Building Knowledge Modelling } \\
\text { (BKM). }\end{array}$ & {$[30]$} & $\begin{array}{l}\text { Further research needed to show how this } \\
\text { platform can be integrated with various } \\
\text { CAFM systems. }\end{array}$ \\
\hline
\end{tabular}


BUSINESS MANAGEMENT AND ASSET MANAGEMENT

FM as a Business Managment Task

FM as an industry field emerges with the international standards emerging

\section{COMPUTERISED FACILTY MANAGEMENT}

CAFM tools bring new management workflows

CAD drawings allow ease of data capture and retrieval

IWMS tools bring new workplace management workflows

\section{BIM LIFECYCLE MODELING}

Whole lifecycle planning in BIM environment

UK Gov Mandate push for better handover of information to building owners

COBie Document outlines new data standards for BIM projects to ease handover for FM

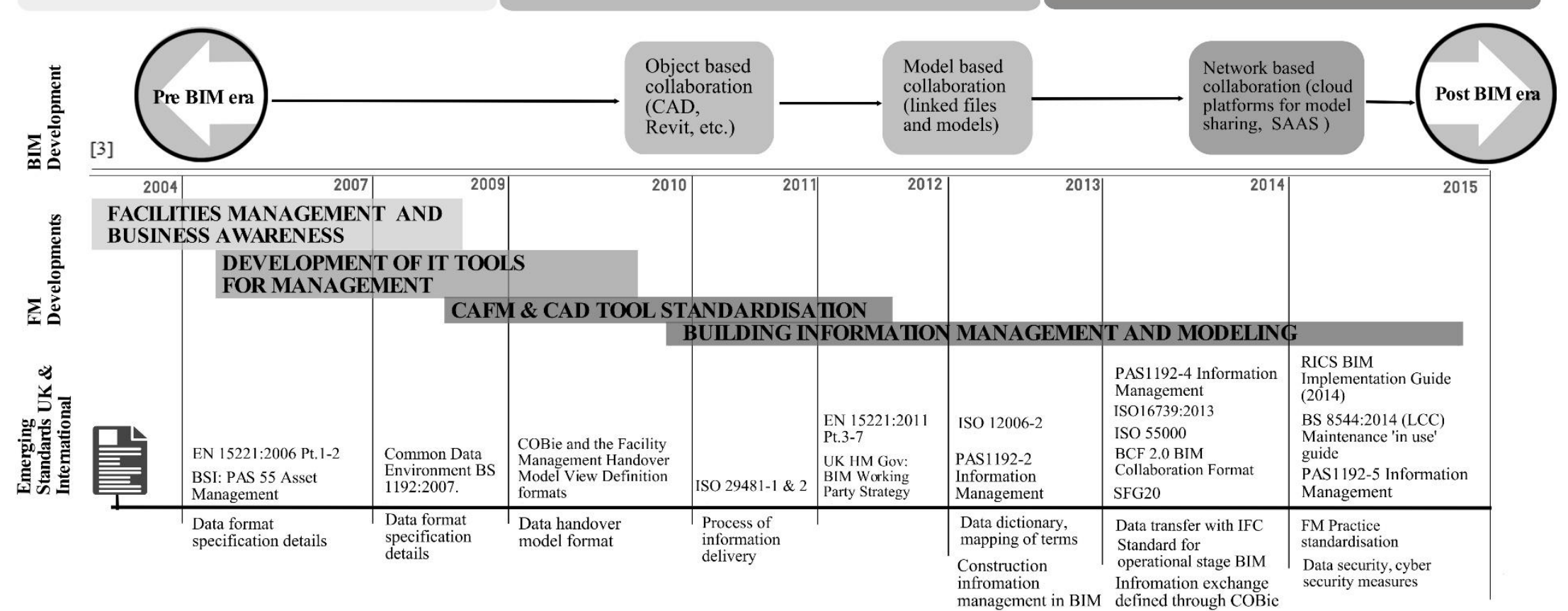


Figure 2 O\&M functions mapped with CAFM, CMMS, and BIM tools.

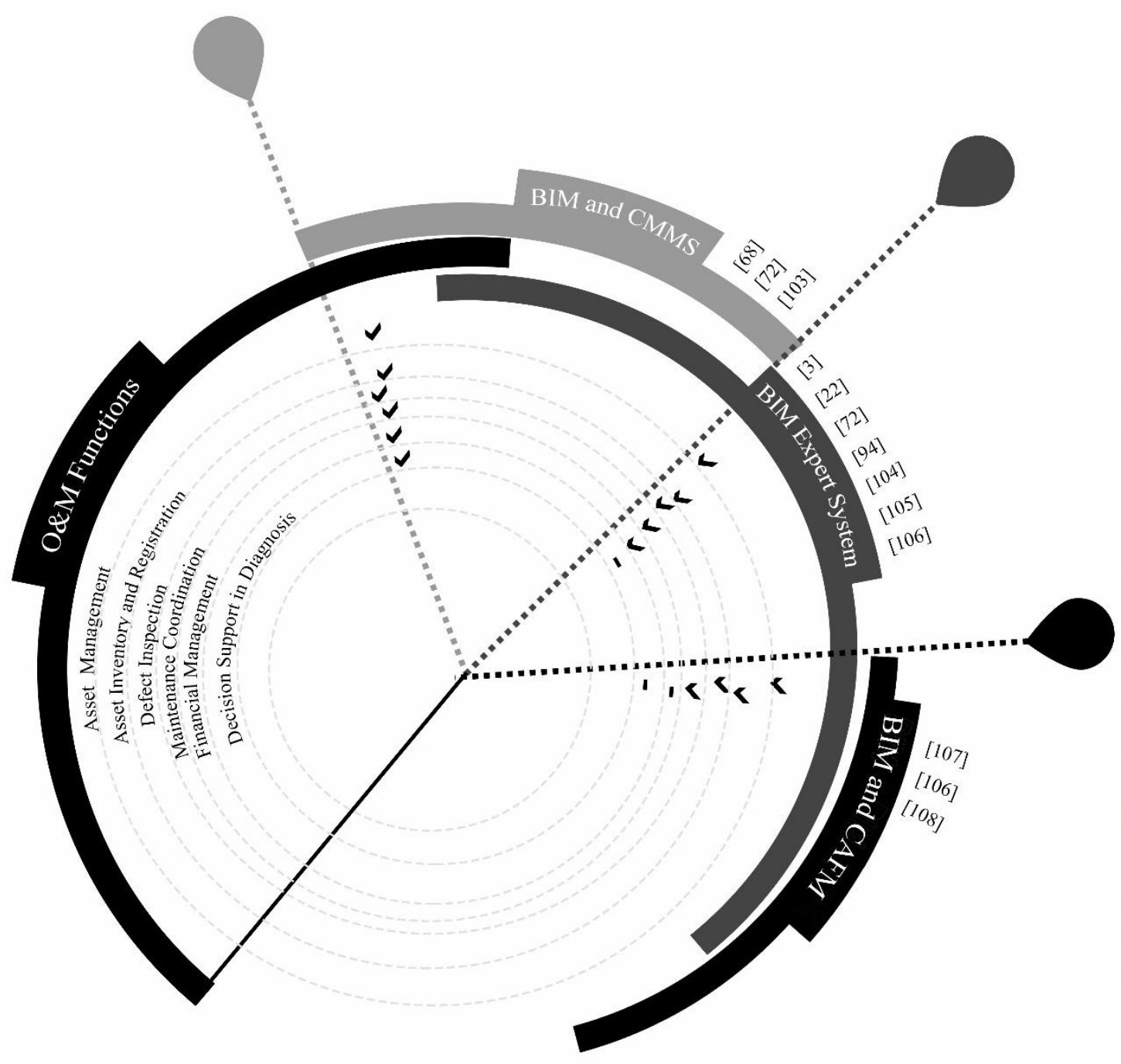




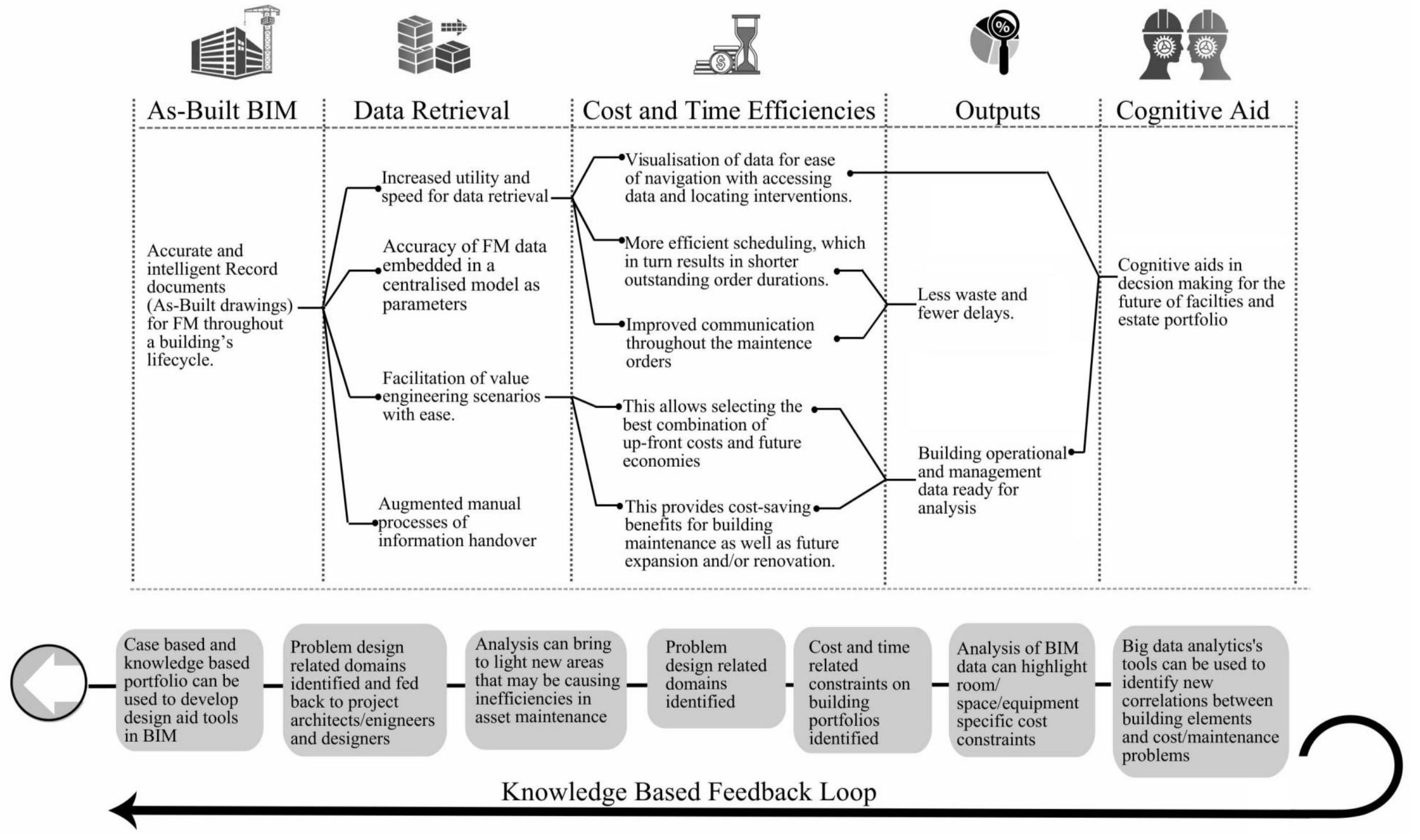




\section{REFERENCES}

432 [1] Eastman, C., Eastman, C.M., Teicholz, P., Sacks, R. and Liston, K. (2011) BIM Handbook: A Guide to Building Information Modeling for Owners, Managers, Designers, Engineers and Contractors, John Wiley \& Sons, Hoboken. ISBN: 978-0470-54137-1

[2] Dubé, L., Bourhis, A. and Jacob, R. (2005) The Impact of Structuring Characteristics on the Launching of Virtual Communities of Practice, Journal of Organizational Change Management, Vol. 18, No. 2, pp. 145-166. DOI: http://dx.doi.org/10.1108/09534810510589570

[3] Succar, B. (2008) Building Information Modelling Framework: A Research and Delivery Foundation for Industry Stakeholders, Automation in Construction, Vol. 18, No.3, pp. 357-375. DOI: http://dx.doi.org/10.1016/j.autcon.2008.10.003

[4] Love, P.E., Matthews, J., Simpson, I., Hill, A. and Olatunji, O.A. (2014) A Benefits Realization Management Building Information Modeling Framework for Asset Owners, Automation in Construction, Vol. 37, pp. 1-10. DOI: http://dx.doi.org/10.1016/j.autcon.2013.09.007

[5] Love, P.E., Simpson, I., Hill, A. and Standing, C. (2013) From Justification to Evaluation: Building Information Modeling for Asset Owners, Automation in Construction, Vol. 35, pp. 208-216. DOI: http://dx.doi.org/10.1016/j.autcon.2013.05.008

[6] Antje Junghans, D., Steenhuizen, D., Flores-Colen, I., Reitsma, A. and Branco Ló, P. (2014) The Road to Facility Management, Facilities, Vol. 32, No.1/2, pp. 46-57. DOI: 10.1108/f-09-2012-0072.

[7] Codinhoto, R., Kiviniemi, A., Kemmer, S. and da Rocha, C.G. (2013) BIM-FM Implementation: An Exploratory Investigation, International Journal of 3-D Information Modeling (IJ3DIM), Vol. 2, No. 2, pp. 1-15. DOI: http://dx.doi.org/10.4018/ij3dim.2013040101

[8] Demkin, J.A. (2006) The Architect's Handbook of Professional Practice, John Wiley \& Sons, Hoboken, New Jersey. ISBN-13: 978-1118308820

[9] Mohandes, S., Abdul Hamid, A. and Sadeghi, H. (2014) Exploiting Building Information Modeling Throughout the Whole Lifecycle of Construction Projects, Journal of Basic and Applied Scientific Research, Vol. 4, No. 9, pp. 16-27. Available on-line

at: http://www.textroad.com/pdf/JBASR/J.\%20Basic.\%20Appl.\%20Sci.\%20Res.,\%204(9 16-27,\%202014.pdf (Accessed: November, 2016).

[10] Azhar, S. (2011) Building Information Modeling (BIM): Trends, Benefits, Risks, and Challenges for the AEC Industry, Leadership and Management in Engineering, Vol. 11, No. 3, pp. 241-252. DOI: http://dx.doi.org/10.1061/(ASCE)LM.1943$\underline{5630.0000127}$

[11] Becerik-Gerber, B., Jazizadeh, F., Li, N. and Calis, G. (2011) Application Areas and Data Requirements for BIM-enabled Facilities Management, Journal of Construction Engineering and Management, Vol. 138, No. 3, pp. 431-442. DOI: http://dx.doi.org/10.1061/(ASCE)CO.1943-7862.0000433

[12] Kassem, M., Kelly, G., Dawood, N., Serginson, M. and Lockley, S. (2015) BIM in Facilities Management Applications: A Case Study of a Large University Complex, Built Environment Project and Asset Management, Vol. 5, No. 3, pp. 261-277. DOI: http://dx.doi.org/10.1108/BEPAM-02-2014-0011

[13] British Institute of Facilities Management, (2013) Benchmarking: Effective Performance Management for FM, British Institute of Facilities Management, UK. 
Available on-line at: file:///C:/Users/pc\%20user/Downloads/3benchmarking-effectiveperformance-management-for-fm-fmlf.pdf (Accessed: November, 2016).

[14] Khosrowshahi, F. and Arayici, Y. (2012) Roadmap for Implementation of BIM in the UK Construction Industry, Engineering, Construction and Architectural Management Vol. 19 No. 6, pp. 610-635. DOI: http://dx.doi.org/10.1108/09699981211277531

Atkin, B. and Brooks, A. (2009) Total Facilities Management, $3^{\text {rd }}$ ed.,Wiley and Blackwell, Hong Kong. ISBN-13: 978-1118655382

[16] Barrett,P. and Baldry, D. (2009) Facilities Management: Towards Best Practice, Blackwell Science, Oxford. ISBN-13: 978-0632050437

[17] Alexander, K. (2013) Facilities Management: Theory and Practice, Routledge, New York. ISBN-13: 978-0419205807

[18] McGregor W. and Then, D.S.S. (1999) Facilities Management and the Business of Space, Arnold, London. ISBN-13: 978-0415503129

[19] Nutt, B. (2004) Infrastructure Resources: Forging Alignments Between Supply and Demand, Facilities, Vol. 22, No. 13/14, pp. 335-343. DOI: http://dx.doi.org/10.1108/02632770410563031

[20] Chotipanich, S. (2004) Positioning Facility Management, Facilities, Vol. 22, No. 13/14, pp. 364-372. DOI: http://dx.doi.org/10.1108/02632770410563086

[21] Cotts, D., Roper, K., and Payant, R. (2010) Facilities Management Handbook, $3^{\text {rd }}$ ed., Amacom, USA. ASIN: B00OVMPMJM

[22] Lee, J.H., Lee, M.S., Lee, S.H., Oh, S.G., Kim, B.H., Nam, S.H. and Jang, J.S. (2013) Development of Computerized Facility Maintenance Management System Based on Reliability Centered Maintenance and Automated Data Gathering, International Journal of Control and Automation, SERSC, Vol. 6, No. 1, pp. 1-12. Available on-line at: http://www.sersc.org/journals/IJCA/vol6_no1/1.pdf (Accessed: November, 2016).

[23] Hinks, J. and McNay, P. (1999) The Creation of a Management-by-Variance Tool for Facilities Management Performance Assessment, Facilities, Vol. 17, No. 1/2, pp. 31 53. DOI: http://dx.doi.org/10.1108/02632779910248893

[24] Gu N., Singh V., London K., Brankovic L. and Taylor C. (2008) Adopting Building Information Modeling (BIM) as Collaboration Platform in the Design Industry, CAADRIA 2008: Beyond Computer-Aided Design: Proc. of the 13th Conference on Computer Aided Architectural Design Research in Asia, The Association for Computer Aided Architectural Design Research in Asia (CAADRIA).

[25] Olatunji, O.A. and Akanmu, A. (2015) BIM-FM and Consequential Loss: How Consequential Can Design Models be? Built Environment Project and Asset Management, Vol. 5, No. 3, pp. 304-317. DOI: http://dx.doi.org/10.1108/BEPAM-032014-0021

[26] Teicholz, P. (2013) BIM for Facility Managers, John Wiley \& Sons, New Jersey. ISBN-13: 978-1118382813

[27] Kamara, J., Augenbroe, G., Anumba, C. and Carrillo, P. (2002) Knowledge Management in the Architecture, Engineering and Construction Industry, Construction Innovation, Vol.2, No.1, pp.53-67. DOI: http://dx.doi.org/10.1108/14714170210814685

[28] IBM Corporation (2013) Implementation Guide for Integrated Workplace Management Software, IBM Corporation, US.

[29] Lin, S., Gao, J. and Koronios, A. (2006) Key Data Quality Issues for Enterprise Asset Management in Engineering Organisations, International Journal of Electronic Business Management (IJEBM), Vol. 4, No. 1, pp. 96-110. Available on-line at: http://ijebm.ie.nthu.edu.tw/IJEBM Web/IJEBM static/Paper-V4 N1/A10E684 3.pdf (Accessed: Novermber, 2016) 
[30] Motawa, I. and Almarshad, A. (2015) Case-based Reasoning and BIM Systems for Asset Management, Built Environment Project and Asset Management, Vol.5, No.3, pp. 233-247. DOI: http://dx.doi.org/10.1108/BEPAM-02-2014-0006

[31] Handzic, M. and Durmic, N. (2015) Knowledge Management, Intellectual Capital and Project Management: Connecting the Dots, Electronic Journal of Knowledge Management, Vol. 13, No. 1, pp. 51-61. Available on-line at: file:///C:/Users/pc\%20user/Downloads/ejkm-volume13-issue1-article656.pdf (Accessed: November 2016).

[32] Warwick, A. (2015) Study Shows UK Workers Fail to Understand Data Value, Putting Firms at Risk, Vol. 2015, 27 June. Available on-line at: http://www.computerweekly.com/news/4500250569/Study-shows-UK-workers-failto-understand-data-value-putting-firms-at-risk (Accessed: November, 2016).

[33] Meng, X. and Minogue, M. (2011) Performance Measurement Models in Facility Management: A Comparative Study, Facilities, Vol.29, No. 11/12, pp. 472-484. http://dx.doi.org/10.1108/02632771111157141

[34] Bollinger, A.S. and Smith, R.D. (2001) Managing Organizational Knowledge as a Strategic Asset, Journal of Knowledge Management, Vol.5, No.1, pp. 8-18. DOI: http://dx.doi.org/10.1108/13673270110384365

[35] Marakas, G.M. (1999) Decision Support System in the Twenty First Century, Prentice Hall, Englewood Cliffs. ISBN-13: 978-0137441860

[36] Uit Beijerse, R.P. (2000) Knowledge Management in Small and Medium-sized Companies: Knowledge Management for Entrepreneurs, Journal of knowledge $\begin{array}{llllll}\text { management, } & \text { Vol. } & 4 & \text { No. } & \text { 2, pp. }\end{array}$ http://dx.doi.org/10.1108/13673270010372297

[37] Bosch, A., Volker, L. and Koutamanis, A. (2015) BIM in the Operations Stage: Bottlenecks and Implications for Owners, Built Environment Project and Asset Management, Vol. 5, No. 3, pp. 331-343. DOI: http://dx.doi.org/10.1108/BEPAM-032014-0017

[38] Bhatt G.D. (2001) Knowledge Management in Organizations: Examining the Interaction Between Technologies, Techniques, and People, Journal of Knowledge $\begin{array}{llllll}\text { Management, } & \text { Vol. 5, } & \text { No. } & \text { 68-75. DOI: }\end{array}$ http://dx.doi.org/10.1108/13673270110384419

[39] Preiser, W.F.E. (1998) Post-occupancy Evaluation, Van Nostrand Reinhold, New York. ISBN-13: 978-1138888326

[40] British Institute of Facilities Management, (1997) Facilities Management Measurement Protocol, Saffron Walden, Essex.

[41] Kaplan, R.S. and Norton, D.P. (1992) The Balanced Scorecard: Measures that Drive Performance, Harvard Business Review, Vol. 70, No. 1, p. 71. Available on-line at: https://hbr.org/2005/07/the-balanced-scorecard-measures-that-drive-performance (Accessed: November, 2016).

[42] Cooper, I. (2001) Post-occupancy Evaluation-where Are You?, Building Research \& Information, Vol. 29, No. 2, pp. 158-163. DOI: http://dx.doi.org/10.1080/09613210010016820

[43] Egan, J. (1998) Britain, Rethinking Construction: The Report of the Construction Task Force to the Deputy Prime Minister, John Prescott on the Scope for Improving the Quality and Efficiency of UK Construction, Department of the Environment, Transport and the Regions London, London. Available on-line at: http://constructingexcellence.org.uk/wpcontent/uploads/2014/10/rethinking construction report.pdf (Accessed: November, 2016). 
[44] Jaunzens, D., Cohen, R., Watson, M., Maunsell, F. and Picton, E. (2002) Post Occupancy Evaluation - A Simple Method for the Early Stages of Occupancy Usable Buildings. Building Research Establishment (BRE). Available online at: http://www.google.com.mx/url?sa $=\mathrm{t} \& \mathrm{rct}=\mathrm{j} \& \mathrm{q}=\&$ esrc $=\mathrm{s} \&$ source $=$ web $\& \mathrm{~cd}=2 \& \mathrm{cad}=\mathrm{rja}$ \&uact $=8 \& v e d=0 C C Q Q F j A B \& u r l=h t t p \% 3 \mathrm{~A} \% 2 \mathrm{~F} \% 2 \mathrm{Fwww} . u$ sablebuildings.co.uk $\% 2$ Ffp\%2FOutputFiles\%2FPdfFiles\%2FFR4p1POEFYCIBSEpaperOct02.pdf\&ei=uEss VISJIYa5yQTUxYCgAg\&usg=AFQjCNFbc08ccBOxr5gFoTzd42kSnUDfJQ\&sig2= UOEuD92kG88ek245v2AX8g\&bvm=bv.76477589 (Accessed: November, 2016).

[45] Zimmerman, A. and Martin, M. (2010) Post-occupancy Evaluation: Benefits and Barriers, Building Research \& Information, Vol. 29, No. 2, pp. 168-174. DOI: http://dx.doi.org/10.1080/09613210010016857

[46] Bassioni, H.A., Price, A.D. and Hassan, T.M. (2005) Building A Conceptual Framework for Measuring Business Performance in Construction: An Empirical Evaluation, Construction Management and Economics, Vol. 23, No. 5, pp. 495-507. DOI: http://dx.doi.org/10.1080/0144619042000301401

[47] European Foundation for Quality Management (1999) Assessing for Excellence: A Practical Guide for Self-Assessment, EFQM. Available on-line at: http://www.flow.de/en/pdf/1203change e.pdf (Accessed: November, 2016).

[48] Wongrassamee, S., Simmons, J. and Gardiner, P. (2003) Performance Measurement Tools: The Balanced Scorecard and the EFQM Excellence Model, Measuring Business Excellence, Vol. 7, No. 1, pp. 14-29. DOI: http://dx.doi.org/10.1108/13683040310466690

[49] Chrissis, M.B., Konrad, M., Shrum, S. (2003) CMMI Guidlines for Process Integration and Product Improvement, Addison-Wesley Longman Publishing Co., Inc., Boston. ISBN-13: 978-0321154965

[50] Paulk, M., Curtis, B., Chrissis M., B. and Weber, C., V. (1993) Capability Maturity Model for Software, Encyclopedia of Software Engineering, Technical Report, pp. 310. Available on-line at: https://www.sei.cmu.edu/reports/93tr024.pdf (Accessed: November, 2016).

[51] Amaratunga, D., Haigh, R., Sarshar, M. and Baldry, D. (2002) Assessment of Facilities Management Process Capability: A NHS Facilities Case Study, International Journal of Health Care Quality Assurance, Vol. 15, No.6, pp.277-288. DOI: http://dx.doi.org/10.1108/09526860210442047

[52] Brackertz, N. and Kenley, R. (2002) A Service Delivery Approach to Measuring Facility Performance in Local Government, Facilities, Vol. 20, No. 3/4, pp. 127-135. DOI: http://dx.doi.org/10.1108/02632770210423885

[53] Felice De Toni, A., Fornasier, A., Montagner, M. and Nonino, F. (2007) A Performance Measurement System for Facility Management: The Case Study of a Medical Service Authority, International Journal of Productivity and Performance Management, Vol. 56, No. 5/6, pp. 417-435. DOI: http://dx.doi.org/10.1108/17410400710757123

[54] Lohman, C., Fortuin, L. and Wouters, M. (2004) Designing a Performance Measurement System: A Case Study, European Journal of Operational Research, Vol. 156, No. 2, pp. 267-286. DOI: http://dx.doi.org/10.1016/S0377-2217(02)00918-9

[55] Varcoe, B.J. (1996) Facilities Performance Measurement, Facilities, Vol.14, No.10/11, pp. 46-51. DOI: http://dx.doi.org/10.1108/02632779610129168

[56] Belcher, R.G. (1997) Corporate Objectives, Facilities, Measurement and Use: A University Model, Proc. of the RICS Cobra Conference, Portsmouth, UK. 
[57] Featherstone, P. and Baldry, D. (2000) The Value Of The Facilities Management Function In The UK NHS Community Health- Care Sector, Facilities, Vol. 18, No. 7/8, pp. 302 - 311. DOI: http://dx.doi.org/10.1108/02632770010340690

[58] McDougall, G., Kelly, J., R., Hinks, J. and Bititci, U., S. (2002) A Review of the Leading Performance Measurement Tools for Assessing Buildings, Journal of Facilities Management, Vol. 1, No. 2, pp. 142-153. DOI: http://dx.doi.org/10.1108/14725960310807881

[59] Loosemore, M. and Hsin, Y. (2001) Customer-focused Benchmarking for Facilities Management, Facilities, Vol. 19, No. 13/14, pp. 464-476. DOI: http://dx.doi.org/10.1108/EUM0000000006204

[60] Marsh, L. and Flanagan, R. (2000) Measuring the Costs and Benefits of Information Technology in Construction, Engineering Construction and Architectural Management, Vol. 7, No. 4, pp. 423-435. DOI: http://dx.doi.org/10.1108/eb021164

[61] Shohet, I.M., Lavy-Leibovich, S. and Bar-On, D. (2003) Integrated Maintenance Monitoring of Hospital Buildings, Construction Management \& Economics, Vol. 21, No. 2, pp. 219-228. DOI: http://dx.doi.org/10.1080/0144619032000079734

[62] Heavisides, B. and Price, I. (2001) Input Versus Output-based Performance Mesurement in the NHS-the Current Situation, Facilities, Vol. 19, No. 10, pp. 344356. DOI: http://dx.doi.org/10.1108/EUM0000000005533

[63] HM Government (2012) Final Report to Government by the Procurement/Lean Client Task Group, Government Construction Strategy, London. Available at: https://www.gov.uk/government/uploads/system/uploads/attachment data/file/61157/ Procurement-and-Lean-Client-Group-Final-Report-v2.pdf (Accessed: November, 2016).

[64] Lin, Y.C. and Su, Y.C. (2013) Developing Mobile-and BIM-based Integrated Visual Facility Maintenance Management System, The Scientific World Journal. DOI: http://dx.doi.org/10.1155/2013/124249

[65] Aouad, G., Cooper, R., Fu, C., Lee,A., Ponting, A., Tah, J. and Wu, S. (2005) nD Modelling - A Driver or Enabler for Construction Improvement, RICS Research Paper Series, Vol.5, No.6. Available on-line at: http://usir.salford.ac.uk/id/eprint/621 (Accessed: November, 2016).

[66] Kelly G., Serginson, M., Lockley, S., Dawood, N., Kassem, M., (2013) BIM for Facility Management: A Review and a Case Study Investigating the Value and Challenges, Proc. of the 13th international Conference on Construction Applications of Virtual Reality, London, pp. 30-31.

[67] Watson, A. (2011) Digital Buildings - Challenges and opportunities, Advanced Engineering Informatics, Vol. 25, No. 4, pp. 573-581. DOI: http://dx.doi.org/10.1016/j.aei.2011.07.003.

[68] Volk, R., Stengel, J. and Schultmann, F. (2014) Building Information Modeling (BIM) for Existing Buildings - Literature Review and Future Needs, Automation in $\begin{array}{lllll}\text { Construction, } & \text { Vol. } & 38, & \text { pp. }\end{array}$ http://dx.doi.org/10.1016/j.autcon.2013.10.023

[69] The Institution of Civil Engineers, (2015) Leveraging the Relationship Between BIM and Asset Management, Available on-line at: https://www.ice.org.uk/getattachment/disciplines-and-resources/bestpractice/relationship-between-bim-and-asset-management/BIM_Modelling-andAsset-Management Position-Paper.pdf.aspx (Accessed: November, 2016).

[70] Jiao, Y., Wang, Y., Zhang, S., Li, Y., Yang, B. and Yuan, L. (2013) A Cloud Approach to Unified Lifecycle Data Management in Architecture, Engineering, Construction and Facilities Management: Integrating BIMs and SNS, Advanced 
Engineering Informatics, Vol. 27, No. 2, pp. 173-188. DOI: http://dx.doi.org/10.1016/j.aei.2012.11.006

[71] McArthur, J. (2015) A Building Information Management (BIM) Framework and Supporting Case Study for Existing Building Operations, Maintenance and Sustainability, Procedia Engineering, Vol. 118, pp. 1104-1111. DOI: 10.1016/j.proeng.2015.08.450

[72] Motamedi, A., Setayeshgar, S., Soltani, M. and Hammad, A. (2013) Extending BIM to Incorporate Information of RFID Tags Attached to Building Assets, 4th Construction Specialty Conference, May 29 - June 1, 2013, Montréal, Québec, pp.1-9.

[73] Meadati, P., Irizarry, J. and Akhnoukh, A.K. (2010) BIM and RFID Integration: a Pilot Study, Advancing and Integrating Construction Education, Research and Practice Second International Conference on Construction in Developing Countries (ICCIDC-II) August 3-5, 2010, Cairo, Egypt, pp. 570-578.

[74] HM Government (2013) Building Information Modeling industrial Strategy: Government and industry in partnership, Government Construction Strategy, London. Available at: https://www.gov.uk/government/uploads/system/uploads/attachment_data/file/34710/ 12-1327-building-information-modelling.pdf (Accessed: November, 2016).

[75] Lavy, S., Liu, R. and Issa, R.R.A (2014) Design for Maintenance Accessibility using BIM Tools, Facilities, Vol. 32, No.3/4, pp.153-159. DOI: http://dx.doi.org/10.1108/F09-2011-0078

[76] Longstreet, B., (2010) Finding the Right Solution to Create an As-built BIM of Portland International Airport's Baggage Handling Facility, Professional Surveyor Magazine, Oct 2010.

[77] Volker, T. (2011) Industry Foundation Classes (IFCs): BIM Interoperability Through a Vendor-independent File Format, A Bentley White Paper, September 2011. Available at: http://consultaec.com.au/white-paper-ifc-bim-interoperability-through-avendor-independent-file-format/ (Accessed: November, 2016).

[78] Bishr, Y. (1998) Overcoming the Semantic and Other Barriers to GIS Interoperability, International Journal of Geographical Information Science, Vol. 12, No. 4, pp. 299314. DOI: http://dx.doi.org/10.1080/136588198241806

[79] Cruz, I.F. and Xiao, H. (2009) Ontology Driven Data Integration in Heterogeneous Networks, Complex Systems in Knowledge-based Environments: Theory, Models and Applications, Springer, Heidelberg, pp. 75-98. ASIN: B00LKDLDYI

[80] Codinhoto, R., Kiviniemi, A., Kemmer, S., Essiet, U.M., Donato, V. and Tonso, L.G. (2013) BIM-FM Manchester Town Hall Complex, Research Report 2, Manchester City Council, University of Salford.

[81] Ghosh, A. and Chasey, A. (2013) Structuring Data Needs for Effective Integration of Building Information Modeling (BIM) with Healthcare Facilities Management, ISEC 2013 - 7th International Structural Engineering and Construction Conference: New Developments in Structural Engineering and Construction, pp. 1471-1476. DOI: 10.3850/978-981-07-5354-2-FAM-5-324

[82] Akbarnezhad, A., Ong, K.C.G. and Chandra, L.R. (2014) Economic and Environmental Assessment of Deconstruction Strategies using Building Information Modeling, Automation in Construction, Vol. 37, pp. 131-144. DOI: http://dx.doi.org/10.1016/j.autcon.2013.10.017

[83] Mirjana D. and Milan, R. (2013) Facility Management: A Paradigm for Expanding the Scope of Architectural Practice, International Journal of Architectural Research: ArchNet-IJAR, Vol. 1, No. 3, pp. 127-139. Available on-line at: file://C:/Users/pc\%20user/Downloads/43-141-1-PB.pdf (Accessed: November, 2016). 
[84] Sabol, L. (2008) Challenges in Cost Estimating with Building Information Modeling, IFMA World Workplace. Available on-line at: http://www.dcstrategies.net/files/2_sabol_cost_estimating.pdf (Accessed: November, 2016).

[85] Alvarez-Romero, S.O. (2014) Use of Building Information Modeling Technology in the Integration of the Handover Process and Facilities Management, Worcester Polytechnic Institute, Dissertation.

[86] The State of Wisconsin (2011) Digital Facility Management Information Handover: Current DSF Practices Industry-wide Movement Future Directions, A Research, Findings and Recommendations Report, Vol. Jul 15. Available at: ftp://doaftp1380.wi.gov/master_spec/Digital\%20FM\%20Handover/FM\%20Findings \&RecRpt.pdf (Accessed: November, 2016).

[87] UNITEC's Integrated Information System, BIM As An Information Sharing Resource For Facilities Management And Operations, UNITEC, Available on-line at: https://www.building.govt.nz/assets/Uploads/projects-and-consents/buildinginformation-modelling/nz-bim-case-study-5-unitec.pdf (Accessed: November, 2016).

[88] Dempsey, J. (2009) A Coast Guard Pilot to Make Better Facility Decisions, Journal of Building Information Modeling, Vol. Fall 26, p26. Available at: https://www.wbdg.org/pdfs/jbim_fall09.pdf (Accessed: November, 2016).

[89] Ding, L., Drogemuller, R., Akhurst, P., Hough, R., Bull, S. and Linning, C. (2009) Towards Sustainable Facilities Management, Technology, Design and Process Innovation in the Built Environment, Spon Press, London, pp. 373-392.

[90] Cesarotti, V., Benedetti, M., Dibisceglia, F., Di Fausto, D., Introna, V., La Bella, G., Martinelli, N., Ricci, M., Spada, C. and Varani, M. (2014) BIM-based Approach to Building Operating Management: A Strategic Lever to Achieve Efficiency, Riskshifting, Innovation and Sustainability, Proc. Conference: XVIII International Research Society for Public Management (IRSPM) Conference, At Ottawa, Canada.

[91] Shen,W., Hao, Q., Mak, H., Neelamkavil, J., Xie, H., Dickinson, J., Thomas, R., Pardasani, A. and Xue, H., (2010) Systems Integration and Collaboration in Architecture, Engineering, Construction, and Facilities Management: A Review, Advanced Engineering Informatics, Vol. 24, No. 2, pp. 196-207. DOI: http://dx.doi.org/10.1016/j.aei.2009.09.001

[92] El-Mekawy, M. and Östman, A. (2010) Semantic Mapping: An Ontology Engineering Method for Integrating Building Models in IFC and CityGML, $3^{\text {rd }}$ ISDE Digital Earth Summit, 12-14 June, Nessebar, Bulgaria.

[93] Korpela, J. and Miettinen R. (2013) BIM in Facility Management and Maintenance The Case of Kaisa Library of Helsinki University, Proc. of 29th Annual ARCOM Conference, Reading, UK, pp. 2-4.

[94] Motamedi, A., Hammad, A. and Asen, Y. (2014) Knowledge-assisted BIM-based Visual Analytics for Failure Root Cause Detection in Facilities Management, Automation in Construction, Vol. 43, pp. 73-83. DOI: http://dx.doi.org/10.1016/j.autcon.2014.03.012

[95] Lindkvist, C. (2015) Contextualizing Learning Approaches Which Shape BIM for Maintenance, Built Environment Project and Asset Management, Vol. 5, No. 3, pp. 318-330. DOI: http://dx.doi.org/10.1108/BEPAM-03-2014-0018

[96] Love, P.E., Matthews, J. and Lockley, S. (2015) BIM for Built Asset Management, Built Environment Project and Asset Management, Vol. 5, No. 3, DOI: http://dx.doi.org/10.1108/BEPAM-12-2014-0062

[97] Alwan, Z. and Gledson, B.J. (2015) Towards Green Building Performance Evaluation Using Asset Information Modelling, Built Environment Project and Asset 
Management, Vol. 5, No. 3, pp. 290-303. DOI: http://dx.doi.org/10.1108/BEPAM-032014-0020

[98] Parsanezhad, P., and Dimyadi, J. (2014) Effective Facility Management and Operations via a BIM-based Integrated Information System. CIB Facilities Management (CFM) 2014 Conference, Copenhagen, Denmark, pp .8

[99] Chen, H.M. and Wang, Y.H. (2009) A 3-dimensional Visualized Approach for Maintenance and Management of Facilities, Proc. of ISARC09, pp. 468-475.

[100] Kincaid, D. (1994) Integrated Facility Management, Facilities, Vol. 12, No. 8, pp. 2023. DOI: http://dx.doi.org/10.1108/02632779410062353

[101] Talebi, S. (2014) Exploring Advantages and Challenges of Adaptation and Implementation of BIM in Project Life Cycle, 2nd BIM International Conference, BIM Forum Portugal, Lisbon.

[102] Keraminiyage, K., Amaratunga, R. and Haigh, R. (2004) A Literature Review of Knowledge Management, Facilities Management and Link Between those Two Disciplines, Research Institute for the Built and Human Environment, University of Salford, London.

[103] Miettinen, R. and Paavola, S. (2014) Beyond the BIM utopia: Approaches to the Development and Implementation of Building Information Modeling, Automation in Construction, Vol. 43, pp. 84-91. DOI: http://dx.doi.org/10.1016/j.autcon.2014.03.009

[104] Sackey, E., Tuuli, M., and Dainty, A. (2014) Sociotechnical Systems Approach to BIM Implementation in a Multidisciplinary Construction Context, Journal of Management in Engineering, Vol. 31, No. 1, A4014005. DOI: http://dx.doi.org/10.1061/(ASCE)ME.1943-5479.0000303

[105] Singh, V., Gu, N. and Wang, X. (2011) A Theoretical Framework of a BIM-based Multidisciplinary Collaboration Platform, Automation in Construction, Vol. 20, No. 2, pp. 134-144. DOI: http://dx.doi.org/10.1016/j.autcon.2010.09.011

[106] Liu, R. and Issa, R. (2012) Automatically Updating Maintenance Information from a BIM Database, International Conference on Computing in Civil Engineering, June 2012, pp. 373-380. DOI: 10.1061/9780784412343.0047

[107] Gnanarednam, M. and Jayasena, S., H. (2013) Ability of BIM to Satisfy CAFM Requirements, Proceedings of the Second World Construction Symposium 2013: Socio-Economic Sustainability in Construction 14 - 15 June, Colombo, Sri Lanka, pp. 12-20.

[108] Rich, S., and Davis, K. H. (2010) Geographic Information Systems (GIS) for Facility Management, Whitepaper, IFMA Foundation, pp. 12-17. Available at: https://foundation.ifma.org/docs/default-source/Whitepapers/foundation-geographicinformation-systems-(gis)-technology.pdf?sfvrsn=2 (Accessed: November, 2016).

[109] Hassanain, M.A., Froese, T. and Vanier, D. (2003) Implementation of a Distributed, Model-based Integrated Asset Management System, Journal of Information Technology in Construction, Vol. 8, pp. 119-134. Available on-line at http://www.itcon.org/2003/10 (Accessed: November, 2016).

[110] Hassanain, M.A., Froese, T.M. and Vanier, D.J. (2001) Development of a Maintenance Management Model Based on IAI Standards, Artificial Intelligence in Engineering, Vol. 15, No. 2, pp. 177-193. DOI: http://dx.doi.org/10.1016/S09541810(01)00015-2

[111] Kyle, B.R., Vanier, D.J., Kosovac, B., Froese, T.M. and Lounis, Z. (2002) Visualizer: An Interactive, Graphical, Decision-support Tool for Service Life Prediction for Asset Managers, Proc. 9th International Conference on Durability of Building Materials and Components, Brisbance, pp. 17-20. 
[112] Chang, C.Y., Huang, S.M. and Guo, S.J. (2007) Medical Records for Building Health Management, Journal of Architectural Engineering, Vol. 13, No. 3, pp. 162-171. DOI: http://dx.doi.org/10.1061/(ASCE)1076-0431(2007)13:3(162)

[113] Yasin, F. and Egbu, C. (2010) Exploitation of Knowledge Mapping Benefits in the Facilities Performance Evaluation Process: A Conceptual Framework, Proc. of the 26th Annual ARCOM Conference, Association of Researchers in Construction Management, Leeds, UK, pp. 799-808.

[114] Chang, C.Y. and Tsai, M.D. (2013) Knowledge-based Navigation System for Building Health Diagnosis, Advanced Engineering Informatics, Vol. 27, No. 2, pp. 246-260. DOI: $10.1016 /$ j.aei.2012.12.003

[115] Costin, A., Shaak, A. and Teizer, J. (2013) Development of a Navigational Algorithm in BIM for Effective Utility Maintenance Management of Facilities Equipped with Passive RFID, ASCE Computing In Civil Engineering, Los Angeles, CA, pp. 653-660.

[116] Charlesraj, V.P.C. (2014) Knowledge-based Building Information Modeling (K-BIM) for Facilities Management, The 31st International Symposium on Automation and Robotics in Construction and Mining (ISARC 2014), pp. 1-6.

[117] Wetzel, E.M. and Thabet, W.Y. (2015) The Use of a BIM-based Framework to Support Safe Facility Management Processes, Automation in Construction, Vol. 60, pp. 12-24. DOI: http://dx.doi.org/10.1016/j.autcon.2015.09.004 